\title{
Turnips for summer milk production
}

\author{
D.A. CLARK', S.W. HOWSE ${ }^{2}$, ROBYN J. JOHNSON ${ }^{3}$ A. PEARSON ${ }^{3}$ \\ J.W. PENNO ${ }^{1}$ and N.A. THOMSON' \\ ${ }^{1}$ Dairying Research Corporation, Private Bag 3123, Hamilton \\ 2 Livestock Improvement Corporation, Newstead, Hamilton \\ ${ }^{3}$ Dairying Research Corporation, Taranaki Agricultural Research Station, PO Box 71 I, Hawera
}

\begin{abstract}
Recently many dairy farmers have sown turnips as a summer feed for lactating cows. This paper reports on a national survey of turnip crops in 1994-95, an experiment on turnip yield responses to $\mathrm{N}$ fertiliser and two short-term supplementary feeding trials. Farmers had on average $4.3 \%$ of their farms in turnips with a mean yield of $7.4 \mathrm{t} \mathrm{DM} /$ ha (range 0 to $15.2 \mathrm{t} \mathrm{DM} / \mathrm{ha})(\mathrm{n}=328)$. Barkant was the highest yielding cultivar and mixtures yielded significantly less than Barkant alone. Rainfall in November and December but not January was positively associated with turnip yield. Fertiliser $\mathrm{N}$ after sowing increased turnip yield by $13.2 \mathrm{~kg} \mathrm{D} / \mathrm{kg} \mathrm{N}$, but fertiliser $\mathrm{N}$ at sowing or $\mathrm{P}$ fertiliser in the three months to sowing had no effect on yield. In contrast to the survey, application of $25,50,100$ or $200 \mathrm{~kg} \mathrm{~N} / \mathrm{ha}$ after sowing at TARS gave no significant increase in total DM yield. Supplementing pasture with 3.6 and $5 \mathrm{~kg}$ turnip DM/cow/day at DRC and TARS gave milksolids responses of 26 and $18 \%$ respectively compared to pasture only. The survey highlighted the variability of turnip yield, and although many growers reached the economic break-even point of 8-10 t DM/ha, there are less risky alternatives to summer turnips such as purchased maize silage and pasture from $\mathrm{N}$-boosted spring pasture.
\end{abstract}

Keywords: Barkant turnips, brassica, dairying, farm survey, milksolids, nitrogen

\section{Introduction}

Key weaknesses of the New Zealand milk production system are: low milk production per cow, lack of consistency in milk composition, and level of processing plant utilisation. A major area of concern is the reduced milksolids yield during summer and autumn: In the North Island decline in milksolids in this period can be as high as $19 \%$ per herd per month compared with a theoretical decline of $7 \%$ per herd per month. Extra summer feed would allow extra milking days in the autumn, produce' a more consistent raw product for processing and give better utilisation of processing plants.

New turnip cultivars have a high yield potential of IO-12 t DM/ha of high quality forage (11-13 MJ metabolisable energy (ME)/kg DM) over 80-120 days (Percival et al. 1986; Notman 1992). Their contribution to total farm profitability will depend on: crop yield, amount of pasture lost, proportion of farm in crop and milksolids response to the turnip supplement. There is no information on either the variability of yields achieved "on farm", or the value of various crop husbandry practices. No self-contained farmlet-scale research has been done. Milksolids response data from Australia (C. Grainger pers. comm.) suggest that responses to turnips may be greater where a high protein supplement is used.

This paper presents survey information on the variability of turnip yield. It examines New Zealand data on yield response to $\mathrm{N}$ fertiliser, and of milksolids response. It uses a dairy farm simulation model to examine the profitability of different turnip yields.

\section{Methods}

\section{Survey}

During January-March 1995 all Livestock Improvement Advisory Consulting Officers throughout New Zealand were asked to sample turnip crops growing in their districts. They were asked to measure crops regardless of yield. Cost precluded a full-scale random survey and crops came mainly from discussion group members. Reticence to provide information on total crop failures means that crop yields are probably biased upwards. Yields were measured by Consulting Officers from eight, randomly located $1 \mathrm{~m}^{2}$ quadrats throughout the crop. Dry matter content was initially assumed to be $11 \%$, but was corrected to $9 \%$ based on experimental results at No. 1 Dairy, DRC and the Taranaki Agricultural Research Station [TARS).

Crop growers were asked for information on: farm area, turnip area, soil type, soil test, topography, cultivation practice, crop fertiliser, turnip cultivar, sowing date and seed rate, weed and insect problems, 
feeding out details, resowing intentions and crop intentions for next year.

Survey data were summarised as means and histograms and multiple regression used to examine associations between turnip yield and various crop practices.

\section{Experiment 1}

A plot trial was sown at TARS in December 1994. Turnips (cv. Barkant) were sown at $1.5 \mathrm{~kg} / \mathrm{ha}$. The trial was a split plot design with $\mathrm{N}$ fertiliser rates as main plots and harvest time as sub-plots with 4 replicates. N fertiliser rates were $0,25,50,100$ and $200 \mathrm{~kg} \mathrm{~N} / \mathrm{ha}$ applied as urea four weeks after sowing. Harvest times were 49, 70,91 and 119 days after sowing. At harvest, turnips were separated into leaf and bulb, and green yield and DM\% determined on each component.

\section{Experiment 2}

A short-term feeding trial comparing pasture with pasture plus turnips was conducted at TARS from 14 February to 3 March 1995. Twenty cows were blocked on the basis of age, liveweight and current production and randomly allocated to one of two treatments: Pasture (allowance of $10 \mathrm{~kg} \mathrm{DM} /$ cow/day above $4 \mathrm{~cm}$ ), or Pasture plus Turnips (allowance of $10 \mathrm{~kg}$ DM/cow/day above four $\mathrm{cm}$, plus $5 \mathrm{~kg} \mathrm{DM} /$ cow/day of Barkant turnips). Turnips were pulled and fed out on the previous days pasture break. On four occasions during feeding turnips were sampled, separated into leaf and bulb and analysed for: in vitro digestibility, neutral detergent fibre (NDF), and total $\mathrm{N}$. ME content was estimated from in vitro digestibility. Daily milk yield and composition were measured on days $7,10,14$ and 17 of the trial. Liveweight and condition score were measured at the start and finish of the trial, and three days after the trial fnished to allow gut fill equilibration.

\section{Experiment 3}

A feeding trial comparing pasture with pasture plus turnips was conducted at the No. 1 Dairy, DRC from 7 February to 26 March 1995. Sixty cows were blocked on the basis of age, liveweight and current production and randomly allocated to one of three treatments: Pasture only, pasture plus turnips (4 kg DM/cow/day), or pasture plus turnips ( $8 \mathrm{~kg} \mathrm{DM} /$ cow/day). Turnips were fed in situ and estimates of pre-grazing mass made to allow turnip DM offered to be calculated. Pasture intake was estimated from pre- and post-grazing mass using calibrated visual assessment in each paddock. Daily milk yield and composition, liveweight and condition score were measured weekly, following a oncweek uniformity period.

\section{Results}

\section{Survey}

Variation in crop yield on a national basis is shown in Figure 1. Mean crop yield was $7358 \mathrm{~kg}$ DM/ha (range $0-15193 \mathrm{~kg} \mathrm{DM} / \mathrm{ha}$ ). It is likely that true mean yield is overestimated because growers were not prepared to allow complete failures or very low yielding crops to be measured. Barkant was the cultivar used in $88.4 \%$ of crops, other cultivars in $7.6 \%$, and a mixture of Barkant and other cultivars in $4 \%$. Yields for Barkant, Barkant mixtures, or other cultivars were $7487,6043,6858 \mathrm{~kg}$ $\mathrm{DM} / \mathrm{ha}$ and were significantly different $(\mathrm{P}<0.05)$. The average proportion of the farm sown in turnips was $4.3 \%$ (range $0.8-17.3 \%$ ).

Mean Northland crop yield was $6620 \mathrm{~kg} \mathrm{DM} / \mathrm{ha}$ (n = 48) and district averages along with December 1994 rainfall are given in Table 1.

Figure 1 Variation in turnip DM yield for New Zealand crops in 1994/95.

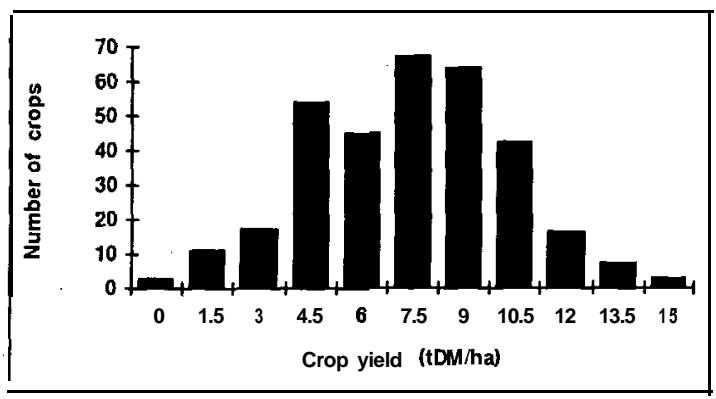

Table 1 Northland district crop yields (means \pm sd) for 1994195 and December 1994 rainfall.

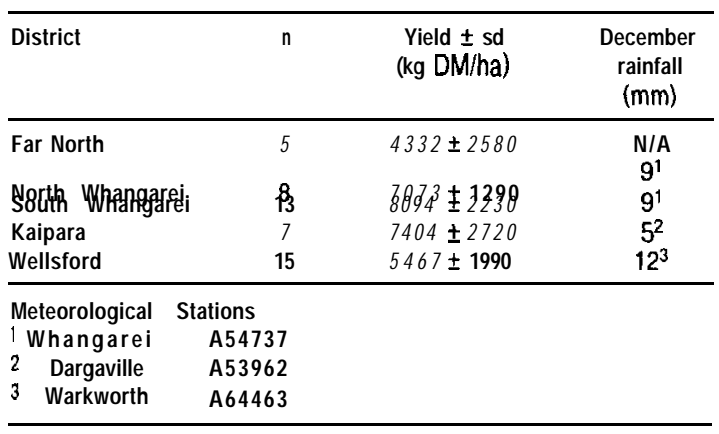

\section{Factors associated with yield}

The following factors were closely associated with turnip yield. 


\section{Rainfall}

Monthly rainfall for November and December was positively associated with turnip yield. Each millimetre of rainfall was associated with 6.8 and $31.2 \mathrm{~kg} \mathrm{DM} / \mathrm{ha}$ extra turnip yield in November and December respectively. Monthly rainfall in January had no significant association with crop yield.

\section{Fertiliser}

Nitrogen applied after sowing was positively associated with crop yield $(\mathrm{P}<0.01)$. Mean $\mathrm{N}$ application rate was $30 \mathrm{~kg} \mathrm{~N} / \mathrm{ha}$ (range $0-145 \mathrm{~kg} \mathrm{~N} / \mathrm{ha}$ ). Mean phosphorus application was $63 \mathrm{~kg} \mathrm{P} / \mathrm{ha}$ (range $0-278 \mathrm{~kg} \mathrm{P} / \mathrm{ha}$ ). For each $\mathrm{kg} \mathrm{N} / \mathrm{ha}$ applied after sowing an associated increase of $13.2 \mathrm{~kg}$ of turnip DM yield was recorded. There was no association between $\mathrm{N}$ fertiliser at sowing or phosphorus fertiliser in the 3 months before sowing, and crop yield.

\section{Sowing date}

Mean sowing date was IO November 1994 (range 24 September to 23 December 1994). There was no association between sowing date and yield. However, time for sowing to measurement was positively associated with yield $(P<0.001)$, with an increase of 41 $\mathrm{kg} \mathrm{DM} / \mathrm{ha}$ /day. The positive association implies that crops were being measured and grazed before maturity. Mean crop growth time was 84 days (range 36 to 153 days).

\section{Experiment 1}

Nitrogen fertiliscr had no effect on total turnip yield or leaf yield at any harvest date. There was a trend for $\mathrm{N}$ fertiliser to increase the leaf:bulb ratio and this was significant $(\mathrm{P}<0.05)$ at the 91-day harvest with mean bulb yields for the $50-200 \mathrm{~kg} \mathrm{~N} / \mathrm{ha}$ treatments less than mean yields for the $0-25 \mathrm{~kg} \mathrm{~N} / \mathrm{ha}$ treatments (Table 2). Similar differences occurred at the 71- and 119-day harvests.

Figure 2 The growth pattern of turnip leaf, bulb and total DM in Experiment 1 at TARS (mean of 4 four $\mathrm{N}$ rates).

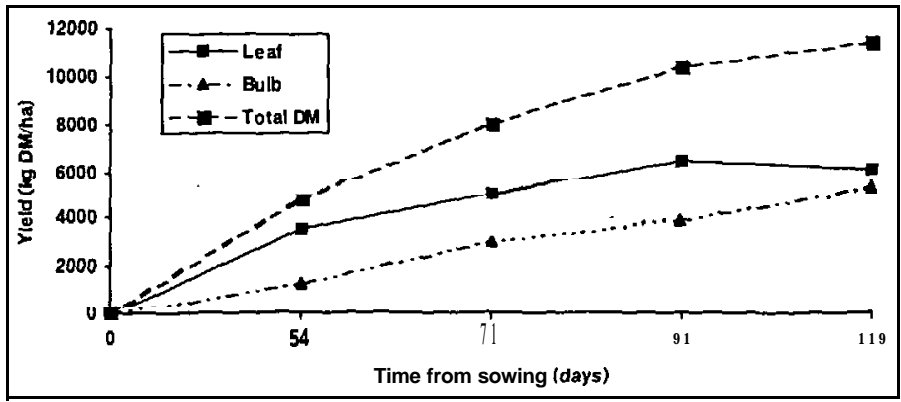

Table 2 The effect of $\mathrm{N}$ fertiliser on turnip leaf, bulb and total DM at 91 days from sowing.

\begin{tabular}{cccc}
\hline $\begin{array}{c}\text { fertiliser } \\
(\mathrm{kg} / \mathrm{ha})\end{array}$ & $\begin{array}{c}\text { Yield (kg DM/ha) } \\
\text { Leaf }\end{array}$ & Bulb & Totą) DM \\
\hline 0 & 6281 & 4549 & 10830 \\
25 & 5652 & 4634 & 10286 \\
50 & 6149 & 3656 & 9805 \\
100 & 6868 & 3306 & 10174 \\
200 & 7538 & 3505 & 11043 \\
LSD 0.05 & 1601 & 1049 & 2207 \\
Significance & NS & & $*$ \\
\hline
\end{tabular}

Table 3 Chemical composition of turnip leaf, turnip bulb and pasture.

\begin{tabular}{|c|c|c|c|}
\hline & Turnip leaf & Turnip Bulb & Pasture \\
\hline DM Digestibility (\%) & 83.2 & 88.8 & 73.3 \\
\hline ME (MJ/kg DM) & 12.2 & 12.2 & 10.3 \\
\hline NDF $(\%)$ & 27.5 & 23.7 & 43.6 \\
\hline Crude protein (\%) & 14.3 & 13.3 & 21.2 \\
\hline
\end{tabular}

The increase in turnip yield over time is shown in Figure 2. Although total yield continued to increase until the final harvest at 119 days, leaf yield decreased at this harvest. Maximum crop growth rates occurred between days 54 and 71 .

\section{Experiment 2}

The turnips had a much higher ME content than summer pasture, but a lower crude protein level (Table 3) However, when used as a supplement with pasture containing $>20 \%$ crude protein, the overall diet would contain sufficient crude protein to meet average NZ cow requirements for mid-lactation.

Animal production results are summarised in Table 4. Turnip feeding increased milksolids (MS) yield by $18 \%$ over pasture alone $(\mathrm{P}<0.01)$. Turnip feeding also increased condition score compared with pasture $(\mathrm{P}<0.05)$, but had no effect on liveweight change. Cows on both treatments lost condition score and liveweight over the 18-day experiment.

\section{Experiment 3}

Results are summarised in Table 5. Pasture intake decreased by 0.18 and $0.12 \mathrm{~kg} \mathrm{DM} / \mathrm{kg}$ DM turnips offered for the low and high turnip allowance respectively. Offering $8 \mathrm{~kg}$ compared with $4 \mathrm{~kg}$ turnips per cow per day did 
not significantly increase milksolids yield. Milksolids yield increased by $26 \%(\mathrm{P}<0.01)$ when turnips were fed, with no affect on liveweight or condition score.

\section{Resowing intentions}

In the survey, growers were asked their intentions for resowing, these are summarised in Table 6.

\section{Discussion}

The survey results show a very large variation in turnip yields. Only $50 \%$ of this variation could be associated with survey variables. More accurate information on soil moisture during early growth, cultivation techniques and soil properties may have improved this situation. However, the most urgent need is to find out the proportion of planned turnip crops that fail and identify the cause(s) of this failure. Survey comments indicated that uneven germination of coated seed was common in drier conditions.

Recent work by Hayward \& Scott (1994) showed that the fertiliser Cropmaster 20 (20: 10:0: 13) gave lower establishment, producing half the plant population of other fertilisers with only $15 \%$ establishment of uncoated, viable seed 30 days after sowing. In a second experiment Cropmaster 20 produced lower plant populations when drilled with both coated or uncoated seed compared with broadcasting. They suggest that the hygroscopic ammonium sulphate draws moisture away from the seed and prevents germination, and also the release of ammonia gas as ammonium sulphate breaks down may kill young seedlings.

The use of drills with separate fertiliser and seed placement will allow the safe use of fertilisers such as Cropmaster 20. The lack of response to $\mathrm{N}$ at sowing in the survey results is surprising and suggests the need for further survey and plot experimentation. A fine tilth and good soil consolidation are essential to ensure good early crop growth and hence early weed suppression.

Most growers are using coated seed and, given the lack of insect problems identified in the survey it appears that coated seed containing insecticide is a worthwhile insurance.

An important survey result was the substantially lower yield from Barkant mixtures compared to either Barkant or other cultivars grown alone. This warrants further controlled small-plot experimentation, but the present recommendation must be to avoid cultivar mixtures. The survey confirmed Australian work (Notman 1992) showing the superiority of Barkant to other cultivars. However, high yielding crops of Barabas, York Globe and Appin were recorded in the survey.

The survey results showed a response of $13.2 \mathrm{~kg}$ $\mathrm{DM} / \mathrm{kg} \mathrm{N}$ applied after sowing, with an average
Table 4 Immediate effect of summer turnip feeding on milksolids yield, cow liveweight and condition score.

\begin{tabular}{|c|c|c|c|c|}
\hline & Pasture & Turnips & Turnip effect & $\begin{array}{ll}\text { LSD } & 0.05\end{array}$ \\
\hline Milksolids & & & & \\
\hline $\begin{array}{c}\text { (kg/cow/day) } \\
\text { cow liveweight }\end{array}$ & 0.99 & 1.17 & 0.18 & 0.09 \\
\hline change $(\mathrm{kg})$ & -26 & -32 & .6 & NS \\
\hline Cow condition & -0.4 & -01 & +03 & $0 ?$ \\
\hline
\end{tabular}

Table 5 Immediate effect of summer turnip feeding on pasture intake, milksolids yield, cow liveweight and condition score.

\begin{tabular}{lcccccc}
\hline & Pasture & $\begin{array}{c}\text { Pasture } \\
4 \mathrm{~kg} \\
\text { turnips }\end{array}$ & $\begin{array}{c}\text { Pasture } \\
8 \mathrm{~kg} \\
\text { turnips }\end{array}$ & $+\mathrm{T}^{*}$ & $\mathrm{~T}^{* k}$ \\
\hline $\begin{array}{c}\text { Pasture intake } \\
(\mathrm{kg} \mathrm{DM/cow/day)}\end{array}$ & 10.3 & 9.6 & 9.3 & -0.7 & -1.0 \\
$\begin{array}{c}\text { Turnips offered } \\
\quad(\mathrm{kg} \text { DM/cow/day) }\end{array}$ & 0 & 3.9 & 8.2 & 3.9 & 8.2 \\
$\begin{array}{c}\text { Milksolids } \\
\quad \text { (kg/cow/day) }\end{array}$ & 0.78 & 0.98 & 0.99 & 0.2 & 0.21 \\
$\begin{array}{c}\text { Cow liveweight } \\
\text { change (kg) }\end{array}$ & +3 & -1 & +4 & -4 & +1 \\
$\begin{array}{c}\text { Cow condition } \\
\text { score change }\end{array}$ & -0.2 & 0.25 & -0.1 & -0.05 & -0.1 \\
\hline
\end{tabular}

* ((Pasture + $4 \mathrm{~kg}$ turnips) - Pasture

'* ((Pasture $+8 \mathrm{~kg}$ turnips) -Pasture)

Table 6 Species planned for resowing in Northland and throughout New Zealand.

\begin{tabular}{|c|c|c|c|}
\hline Species & Northland & Rest of & New Zealand \\
\hline Ryegrass-White clover & 36 & & 257 \\
\hline Italian ryegrass & 10 & & 6 \\
\hline Other crops & 0 & & 8 \\
\hline Oats & 2 & & 5 \\
\hline Alternative grasses & 0 & & 4 \\
\hline & 48 & & 280 \\
\hline
\end{tabular}

application of $30 \mathrm{~kg} \mathrm{~N} / \mathrm{ha}$. This is only half that recorded on farm trials in Victoria (Notman \& Mulvany 1994) for urea applications of 29 and $58 \mathrm{~kg} \mathrm{~N} / \mathrm{ha}$, in a season of above-average rainfall. In contrast, almost all districts in the New Zealand survey had below-average December rainfall, many areas receiving less than 20 $\mathrm{mm}$. Both results contrast with those of experiment 1 at TARS where $\mathrm{N}$ rates of $\mathrm{O}-200 \mathrm{~kg} \mathrm{~N} / \mathrm{ha}$ did not increase either leaf or total DM yield. The 'TARS experiment used a basal application of $18 \mathrm{~kg} / \mathrm{ha}$ of $\mathrm{N}$, $\mathrm{P}$ and $\mathrm{K}$ at sowing but densities for all treatments were 20-30 plants $/ \mathrm{m}^{*}$. There is an obvious need for more research on this topic because if the "on farm" results are correct it offers a profitable way to obtain higher 
yielding crops. However, if responses are low and rates up to $145 \mathrm{~kg} \mathrm{~N} / \mathrm{ha}$ are used there is a potential nitrate poisoning risk.

Notman \& Mulvany (1994) calculated most profitable yield responses would occur with fertiliser inputs of $500 \mathrm{~kg}$ superphosphate $/ \mathrm{ha}+125 \mathrm{~kg}$ urea/ha. New Zealand growers used slightly higher levels of superphosphate on average but only half the recommended level of N. However, many growers withheld $\mathrm{N}$ because of the extremely dry conditions.

Survey information on yield and time from sowing showed the importance of letting Barkant crops grow as long as possible to obtain high yields. Experiment 1 showed that total DM yield was still increasing at 119 days from sowing, although leaf yield peaked at 91 days, while bulb yields continued to increase rapidly from 91 to 119 days. This decrease in leaf: bulb ratio may influence utilisation rate but grazing between 80 and 120 days should allow high utilisation of nearly maximum yields with little risk of major losses from leaf senescence or bulb-rot. Highest yielding crops in the survey were those planted in the last 10 days of October, Early planting has greater risk of poor tillage due to wet soils, but has the major advantage of optimal soil moisture and temperatures for high initial growth rates, together with good conditions for $\mathrm{N}$ application. A further advantage is that crops are available for grazing by mid-January without major yield sacrifices, and pasture can be resown early to reduce the pasture loss penalty.

The response to turnip feeding was 36 and $39 \mathrm{~g}$ milksolids(MS)/kg turnip DM offered for Experiment 2 and 3 respectively. These are well below the $100 \mathrm{~g} \mathrm{MS} /$ $\mathrm{kg}$ DM response assumed by Notman (1992) in calculating the economic returns from a turnip crop. Calculations of response depend, of course, on the amount and quality of the basal diet. In both experiments reported here pasture quality was higher than "droughtstressed" summer pasture. Both responses are the "immediate" response to supplementation; "carryover" effects are likely where supplemented cows gain condition score or liveweight or where pasture cover increases as a result of substitution of crops for pasture. In Experiment 2, turnips increased cow condition score by 0.3 units, but cow liveweight did not change. In experiment 3 neither condition score nor liveweight were affected. Therefore, carryover effects, although not measured, are predicted to be small. Substitution rates of $0.19-0.28 \mathrm{~kg}$ DM/ha turnip DM also suggest that carryover effects from the pasture-sparing effect of turnip feeding are likely to be low.

When the basal diet is good quality pasture and cows have not experienced turnips before full acceptance can take up to 2 weeks, especially for the bulbs. This needs to be recognised and other forms of supplement made available during this period, if milk yield is not to fall.

Farmers were not specifically asked to identify health problems, but no comments were received on nitrate poisoning or other illnesses associated with brassicas. However, where $\mathrm{N}$ dressings have been heavy, or environmental conditions favour nitrate build-up, test samples should be taken before feeding.

Clark (1995) used the UDDER simulation model to predict the break-even turnip crop yield for three different January-February pasture growth rates corresponding to normal, dry and drought years. In dry or drought years turnip yields eaten had to be $8 \mathrm{t} \mathrm{DM} / \mathrm{ha}$ to achieve break-even, and in a normal year $10 \mathrm{t} \mathrm{DM} / \mathrm{ha}$. These figures are much higher than the $2.8 \mathrm{t} \mathrm{DM} / \mathrm{ha}$ calculated by Notman (1992), although he used a partial budget approach based on $100 \mathrm{~g}$ MS/kg turnip DM response and without allowing for pasture DM lost as a result of cropping. Gross margins in the UDDER simulation were very sensitive to cropping costs. Given that the survey results showed a loss of only $2.7 \mathrm{t}$

$\mathrm{DM} /$ ha for direct drilling compared to either broadcasting or drilling into a cultivated seedbed, the cost savings associated with direct drilling may be justifiable, especially where soil conditions preclude cultivation and an early crop is required.

Most farmers are using $<6 \%$ of their effective farm area for turnips. On high-stocked farms larger proportions may reduce the area available for pasture silage in spring and reduce pasture available in late spring and autumn. A crop failure will increase effective stocking rate from November to May. Farmers generally have been pleased with the feed available from turnips, even where only 5-6 t DM/ha have been obtained. They cite the "peace-of-mind" value of having an assured source of feed available in a dry summer.

However, this source of feed can be provided by other options at lower risk. For example, a 100 ha farm could buy 2 ha of maize silage on contract to provide the same amount of feed as 4 ha of turnips. Alternatively, the use of $100 \mathrm{~kg} \mathrm{~N} / \mathrm{ha}$ on a 30 ha silage area at a response of 15: 1 will provide a similar amount of extra DM, without the expense and risk of re-establishing pasture.

Growing turnips offers the opportunity of a clean seedbed to establish alternative pasture species. The value of these have been widely advocated for dairying. However, Table 6 shows that only $1.2 \%$ of growers intended to resow turnip areas with grasses other than ryegrass. Surprisingly few growers intended to grow a winter crop, followed by a second crop of turnips in an effort to reduce the total cost of this form of supplementary feed. 


\section{Conclusion}

Turnips are capable of providing an economic source of summer feed. However, the large variation in crop yields emphasises the risky nature of this crop. The conflict between survey and experimental results on $\mathrm{N}$ application after sowing highlights the need for more work on this subject. There is a need for farmlet systems work to provide more precise data on immediate and carryover effects on milksolids yield.

\section{ACKNOWLEDGEMENTS}

To Peter Bodeker and all Livestock Improvement Advisory Consulting Officers who made the measurements of turnip yield. To all farmers who so conscientiously provided data on turnip husbandry, and Rhonda Sutherland and Lesley Standing for statistical analysis and data entry.

\section{REFERENCES}

Clark, D.A. 1995. Summer milk - pasture and crops. Proceedings of the Ruakura Farmers' Conference 47: 10-16.

Hayward, G.D.; Scott, W.R. 1993. The effect of fertiliser type on brassica establishment and yield. Proceedings of Agronomy Society of New Zealand 23: $35-40$.

Notman, P. 1992. Survey of turnip yield in Victoria, Australia. DRDC report.

Notman, P.; Mulvany, J. 1994. Turnip crop fertilisers requirements and herbicide usage trial report. DRDC report.

Percival, N.S.; Bond, D.I.; Hunter, R.M. 1986. Evaluation of new forage brassica cultivars on the Central Plateau. Proceedings of the Agronomy Society of New Zealand 16: 41-48. 